\title{
THEMATIZATION OF CULTURAL PRACTICES IN THE CONTEXT OF PSYCHOLOGICAL COMPENSATION
}

\section{Kopiyevska O. R.}

\section{INTRODUCTION}

Present-day has actualized the issue of cultural practices transformation, their meaningful functional content which will provide a variety of Ukrainians' needs.

Cultural practices are a powerful compensatory tool. The substantial essence of cultural practices can provide a variety of human needs, including psychological ones.

By cultural practices, we mean "the subject-practical activities of a person/people related to the creation or distribution of cultural products. Cultural practices arise from the scope of meanings of socio-cultural existence, and individual human life, thus are conceived, represented, and implemented within available, personalized axiological horizon"

Thematization of cultural practices in the context of psychological compensation provides the scientific understanding and theoretical justification of functional components which will allow describing in detail the development of the algorithm, methods of effective implementation in practice.

It should be emphasized that the understanding of the psychological and compensatory component of cultural practices is actualized in connection with the global intercultural processes that have actively entered the Ukrainian reality.

In our opinion, it is in the analysis of transformational processes in the cultural practices of Ukraine of the late XX - early XXI century through the prism of global, glocal, and local one should take into account the problem of the discrepancy between the established strategies of cultural creation and the cultural realities of today, which require fundamentally different approaches to the development and implementa-

\footnotetext{
${ }^{1}$ Копієвська О.Р. Трансформаційні процеси в культурних практиках України: глобальний, глокальний контекст та локальні особливості (кінець XX - початок XXI ст.) : дис. ... д-ра культурології : 26.00.06. Київ, 2018. С. 72.
} 
tion of effective socio-cultural transformations to ensure and implement psychological balance. The mentioned issue determines mostly the range of problems that are associated with the interdisciplinary understanding of the research topic that we violate that requires scientific justification, practical prospects, and study.

In addition, in our opinion, recourse to categories of "practices" and updating the study of cultural practices are managed not only by the pragmatic turn, the specificity of which is, in particular, and the refusal of the opposition of private and public in favor of intermediate regimes, their coordination, and the change of paradigm of thinking and the whole complex of turns, which occur in the second half of the XX century which confirms the interdisciplinary nature of the particular concept. Defining the contours of the twists and turns concerning the thematization of cultural practices would contribute to the expansion and diversity of cognitive tools knowledge of the psychological and compensatory reality of human existence.

\section{Theoretical understanding of the psycho-compensatory potential of cultural practices}

For a long time, changes in cultural practices theorists associated with global changes that cover different areas of human life.

Changes taking place in modern Ukraine require to focus on the features of modern cultural practices which unfortunately are not always characterized by positive results and effects on the consciousness of Ukrainians, especially the young people.

That is a reason why the modern scientific community actualizes the need to study a number of related issues, namely: the impact of these processes on mental changes, the identification of society and personality; the development of value priorities in current conditions of development in Ukraine. The issues of the role and importance of cultural practices in the system of formation of the cultural landscape and functioning of the primary network of cultural institutions, which in our opinion are the primary producers of cultural services, are updated.

Consideration of the peculiarities of the processes under study led mostly to the analysis of the spectrum of problems that arise in the process of domestic cultural transformations, the development of effective 
practices to overcome the negative consequences of global transformation for Ukraine, its local areas and territories.

G. Nourishev delineates the geo-cultural space in its local mode as a system of stable cultural realities and events that are formed on a particular territory as a result of the coexistence of overlapping, interaction, the collision of faiths, cultural traditions and norms, values, underlying psychological structures of perception and functioning of the world. ${ }^{2}$

Namely, the local context of the development of modern cultural practices that actualizes the issue of transmission of traditions from generation to generation raises the question of preserving mental characteristics and the corresponding national interest.

In our opinion, the traditional and mental allow compensating psychologically for national among the challenges of the global world.

In this context, there is an urgent need to understand the problem which will solve a significant number of various problems, including the role of cultural practices in the psychological compensation of human desires and needs.

Considering the recompense as a specific compensation for expended effort, as balancing emotional states, we focus on the exceptional importance of social practices, cultural in particular, which are characterized by a powerful communicative and compensatory potential and, accordingly, conceptualized various scientific trends and theories.

Due to the features and subject content of theoretical psychological knowledge and its practical value category of compensation is one of the keys.

Thus, the subject of acute discussions is the understanding of various factors affecting the psychological state of a person, the study of compensatory phenomena and aspects.

It is worth noting that each branch of knowledge is characterized by its own, different from the other way of conceptualization and the inclusion of psychological compensation in the scientific tradition. Such specificity is also associated with optics vision the individual authors of the implementation of the individual research programs and the fact that Paul Ricœur has called "engaged subjectivity involved due to the expected objectivity"3.

\footnotetext{
${ }^{2}$ Нурышев Г.Н. Геокультура : теоретико-методологические основания. URL: http: //www.ibl.ru/konf

${ }^{3}$ Ричард Дж. Так что же такое культурне исследования? // Логос. 2012. № 1. С. 36.
} 
By acquiring an interdisciplinary focus, the practice focuses on dialogue, rejection of absolutization and universalization, demonstrates the ability to "hear the truth of Another." The mentioned fact is especially actual in the context of the cultural practices since any culture within which it is formed is not a self-contained monad. Theorists of the dialogical concept of culture (M. Bakhtin, V. Bibler, M. Buber) proceed from the fact that each culture, despite its uniqueness, is able to live and develop only on the edge of cultures, in dialogue with other cultures, and without such interaction, what is defined as intercultural dialogue, it is doomed to degradation.

The practice is understood not only as a phenomenon of action but also as a phenomenon of culture, knowledge, and cognition; it is investigated in the discourse of strategies of thinking and life, tradition and innovation. Among scientists, there are attempts to distinguish the concepts of practice, activity, and action, since they are identified practically on the basis that they belong to the theory of macro-level. ${ }^{4}$

A slightly different approach is proposed by A. Dyakov, who believes that the structure of the practice includes the categories "action" and "activity", where the latter is understood as a specific practice. In the structure of practice, he distinguishes two main components: internal and external. Internal-contains spiritual and volitional efforts of the person, and the main category of analysis when considering it, he considers the concept of moral action. "External" practice is an instrumental-objective relationship of a person to the world; the equivalent of this concept is the concept of material-objective activity ${ }^{5}$.

These are complex issues and require independent, in-depth research, which, despite the importance, goes beyond the objectives set in the thesis. However, for us, the vital question of background, as V. Volkov and O. Kharkhordin emphasize environment character of the practices. "The simplest understanding of background practice is simply the activity context in which a statement or behavior is interpreted." That is, the background is the context within which the individual acts ${ }^{6}$.

\footnotetext{
${ }^{4}$ Смирнов А.В. Дискурсивные практики как инструмент исследования повседневности // Вестник Орловского государственного университета. Сер. Новые гуманитарные исследования. 2012. № 2 (22). C. 264-267.

5 Дьяков А.А. Философия и практика: было ли прошлое, есть ли настоящее, будет ли будущее? // Наука. Философия. Общество : материалы V Российского философского конгресса. Новосибирск, 2009. T. I. C. 435.

6 Волков В.В., Хархордин О.В. Теория практик. СПб. : Европейского университета в СанктПетербурге, 2008. 298. С. 18.
} 
It should be clarified that the concepts of figure and background are used in Gestalt psychology (M. Wertheimer, K. Koffka), where their relationship plays a semantic and system-forming role. The figure is more important than the background, which is the basis. The idea of the background practices borrows from the works of the late L. Wittgenstein, G. Garfinkel, and develops its concept practices. The opponent of the theory of practices. Volkov and A. Gerhardy and developer of the theory of frames V. Vakhshtein write that in L. Wittgenstein, the context of practical action is comprehended in the categories "background" or "framework"). Accordingly, the practice itself, which is in the foreground, is seen as a"figure in the background" ". The scientist also analyzes the metaphor of the background and figure, where the background is the context, and the figure is any everyday practice. The context, understood as a background, is something "visible, but not seen." The researcher also draws attention to the fact that "the practice act and its context (described through another practical act) change places in the process of their interpretation analysis" 8 .

Without going into the controversy between the authors of the theory of practices and frames, we want to pay attention to the dynamic and inversion nature of the "figure-background", that is, practice and context, and their spatial and temporal ordering. In the deployment space of the "figure-background" disposition, the figure will be the practice, and the background is the context, the background of the implementation by active producers of the algorithm of a particular practice. If the background, as A. Dyakov writes, "denotes the entire palette of the semantic content of life, based on which the research thinking distinguishes this or that activity, this or that practice", thus, the background, context, and framework is culture. $^{9}$

Moreover, all practices at the same time, become "a priori background - that is, socio-cultural", which becomes "a common feature, an attribute of practice as such"

\footnotetext{
7 Вахштайн B.C. «Практика» vs. «фрейм»: альтернативные проекты исследования повседневного мира // Социологическое обозрение. 2008. Т. 7. № 1. С. 65.

${ }^{8}$ Вахштайн В. Социология повседневности и теория фреймов. СПб. : Европейского университета в Санкт-Петербурге, 2011. С. 51.

${ }^{9}$ Дьяков А. Теория практик: Социально-философский потенціал концепции // Известия Саратовского университета. Философия, Психология. 2011. № 1. С. 9-12.

10 Настояща К.В. Атрибуції поняття практики: колізії означення і пошуки верифікацій // Грані : науково-теоретичний альманах. 2018. Т. 21. № 1. С. 57.
} 
Restructuring the subject field of socio-humanitarian knowledge in the context of various rotations and increasing interest in culture eliminates the markers of interdisciplinary spaces. Decisive shifts in scientific discourse at the turn of 1970-1980s have been associated with the dissemination of methods of cultural anthropology, social psychology, linguistics (especially the history of mentalities and popular culture), with the formation of sustained interest in microhistory, the return from analysis impersonalized structures to the study of the individual, specific life situations ${ }^{11}$.

Thus, considering the phenomenon of compensation in psychological knowledge, we have to state that we interpret the latter as a specific protective mechanism, human ability, which is aimed at the independent settlement of their problems, complexes, desires, expectations and the like. In the decision of the specified settlements not aby what role belongs to cultural practices which comprehension demands the personal (individual) approach in the context of socio-cultural identification of human potential.

The global revision of the socio-cultural identification of a person has always led to a change of outlook, in particular, the system of values. It is the human system of values, its transformation that allows a person to rethink the own psychological characteristics.

By understanding the world, a person decides what is essential to life and what is not, what is essential, and what is not vital, what he/she can do without, and what is not. Concerning the culture of the individual, we can say that value is something without which the existence of this person loses its meaning entirely or partially. Any system of values is dynamic and mobile: it is transformed in time with age, change of life circumstances, etc. The personality develops (or accepts readily) system of values which allows being guided in the world, to distinguish important from unimportant, necessary from unnecessary. At the same time, the more durable and conscious system of emotional and value orientations, the more stable personal self-consciousness, the more purposeful human activity.

Value is an integral element of any activity, and therefore of all human life. Even Socrates and Plato turned to the problem of value, in medieval theorizing that moved mainly from the theoretical ("heavenly")

\footnotetext{
${ }^{11}$ Раздина Е.В. Трансформация национального государства в мировой системе институтов власти под влиянием процессов глобализации // Гуманітарний часопис : зб. наук. пр. Харків : XАI, 2010. № 2. C. $121-127$.
} 
world to the real ("earthly"); obviously, the value approach prevailed. However, as a philosophical category "value" entered into scientific circulation in Modern times. Thus, in the works of T. Hobbes, G.V. Leibniz, B. Spinoza values are defined as a manifestation of the human emotional sphere, desires. Feelings are the source of values. G. Lotze expressed the opinion that it is necessary to clearly distinguish the world of phenomena and the world of internal values. Based on the categorical status of value, philosophy of value, or axiology, was formed.

Since the mid-twentieth century, the interpretation of the category values in Western philosophy has occurred. A lively discussion started various directions in understanding the value (value as an idea and as an expression of subjective desire). It should be noted that in Ukraine, only in recent decades began an ongoing study of the problem of values. The mentioned fact was facilitated by the transformation of the old system of values and the search for a new value orientation of social and personal life.

The most valuable for the individual are those objects of the world that correspond to its spiritual, material, social needs, moral principles, attitudes, and ideals. Therefore, an essential feature of culture is that systems of cultural values are formed based on the selection of certain types of behavior. It is believed that this selection is based on both spontaneous and conscious desire for consolidation, which provides the best conditions for the survival of the ethnic group. One of the factors of such consolidation is the union of the value system in the form of certain cultural traditions which are transmitted from generation to generation as significant socio-cultural normative regulators of all spheres of social and individual life of the ethnic group.

Of course, there are still nonconformist values (or marginal), where value is rejected not because it is terrible in itself, but only because it is not recognized in society. Indifferent attitude to the values of A. Esin explains that the person is based on their values, which may not coincide with the officially recognized ones ${ }^{12}$.

It is clear that during the radical transformation that we are now experiencing, there is a change in the fundamental norms of regulation. A radical change in the system of values can lead to destabilization of society, chaos in public relations, General marginalization, loss of ethnic

\footnotetext{
12 Межуев В.М. Ценности современности в контексте модернизации и глобализации // Информационный гуманитарный портал «Знание. понимание. умение». Философия. Политология. 2009. № 1 .
} 
identification. There is a need to identify the spiritual and value foundations on which the future bases. The future of society largely depends on how the value foundation will be formed.

As a rule, when we talk about relations between people and cultures, we emphasize the need for a tolerant attitude to each other. There are many different cultures in the world, and almost all of them interact with each other. Due to culture, the intercultural dialogue emerges between representatives of different ethnic, national, and religious communities, which is based on the values characteristic of this culture, one of which is tolerance. Scientists tend to research the essence of the problem of tolerance more often but use different content in this concept. Linguists see tolerance as toleration, political scientists explain it as the ability of the individual and the human community to listen and respect others.

According to psychologists, tolerance is the ability of a person to understand another person, to feel and be aware of the person's feelings and emotions ${ }^{13}$.

Tolerance means understanding; it recognizes the right of other cultures to exist. Tolerant civil culture assumes, firstly, that the individual with the own system of values is not suppressed, and secondly, tolerance of the culture of society is manifested in the fact that other civil cultures also retain the right to exist. Exploring the phenomenon of tolerance, American psychologist Gordon Allport identified three types of tolerance: tolerance as a system of attitudes related to ethnic and racial differences, comfortable tolerance, and tolerance as a trait. From ethnic attitudes, tolerant of the individual is configured according to G. Allport, believes that "all people are equal: group identity in most cases does not matter. Tolerance as a trait means a respectful attitude of its bearer to other people. This respect is manifested in different lifestyles and life strategies. Some people carry a charge of love and goodwill, appreciate group differences from an aesthetic point of view, and find them attractive. The other ones associated the attitude to different groups with the concept of international friendship ${ }^{14}$.

Different interpretations of the concept of tolerance are united by the idea of a positive attitude of tolerance to the preservation, development, respect for cultural identity. In this context, tolerance is an essential

\footnotetext{
13 Почебут Л.Г. Взаимопонимание культур: методология и методы этнической и кросс-культурной психологии. Психология межэтнической толерантности. СПб. : Изд-во С.-Петерб. ун-та, 2005. С. 73.

${ }^{14}$ Кондратьев М.Ю., Ильи В.А. Азбука социального психолога-практика. М. : ПЕР СЭ, 2007. С. 34.
} 
component in determining the priorities of national interests; preservation and development of the cultural potential of the nation; peacekeeping orientation of international cultural cooperation. A tolerant attitude to other cultures and nationalities is actualized in the process of integration of national culture into the European civilizational space. Intercultural dialogue and tolerance are defined in their psychological and practical interaction. Intercultural interaction contributes to the enrichment of spiritual values, the growth of interest in other cultural traditions and religions. The realities of today show that new information systems expand opportunities for intercultural communication as well as help representatives of different ethnic groups organically join the world cultural space. The mentioned aspect creates a tolerant attitude towards other peoples and, accordingly, reduces feelings of rejection, discrimination, exclusion, and intolerance. It is only the reduction of these feelings that leads to psychological stability and balance among the participants of cultural practices.

The nature of value is perfect. According to Y. Bilodid (however, all philosophers agree with this, and no one denies this idea), the value in its origin is generated by the formation of the ideal world of man and contributes to its self-assertion in society. One of the functions of value is to connect the past and the future in the modern human being. In our opinion, this is a good idea, although controversial. Thus, from the midtwentieth century, humanity has mapped new values associated with success in science, technology, and industry. There have been significant changes in the level and quality of life. All that was encouraging opened outlook created a belief in stability, has formed a value-based imperative. At the same time, humanity realized that technology is not only able to facilitate life, to give material well-being, but also to destroy nature. The technique is the field of realization of the creative imagination of a person, but it also generates psychological dependence of a person ${ }^{15}$.

There is no doubt that values are the basis of worldview. At the same time, it should be remembered that the world of values of a culture can never be entirely adequately transformed into the world of another culture. This transformation should take into account the psychological characteristics of the person.

\footnotetext{
15 Бессонова О.Э. Раздаточная экономика России : Эволюция через трансформации. М. : Российская политическая энциклопедия (РОССПЭН), 2006. С. 18-20.
} 


\section{The psychological phenomenon of global transformations in cultural practices}

Transformations caused by globalization, significantly change the moral, ethical, and psychological state of the human, and therefore the Ukrainian society as a whole. Therefore, there are destructive changes in social, individual consciousness. In particular, there is a growing concern of the world community concerning violence, drug addiction, ethnic conflicts, etc. World cultural picture, identifying destructive changes, requires the search for optimization strategies and adequate perception of contemporary cultural reality, which in turn predetermines the necessity of forming a new, global ethic, which on the background of intercultural tensions and "civilizational clashes" is gaining speed.

American Russian Americans theorist N. Epstein, who studied the transformational processes of the late twentieth century, notes the "lag of man from humanity" and explains this by the growing disproportion between the development of human individuality, limited by biological age, and the socio-technological development of mankind, for which the time limit is not set (at least no one knows). With each generation, a person is forced to learn a more and more voluminous load of knowledge and impressions that were accumulated by previous centuries and that it is not able to assimilate. Hence, as the theorist notes, the problem of alienation, outlined in the nineteenth century, and the problem of loss of reality - in the twentieth century.

Scientists associate the specifics of communication reflection with the processes of globalization, which are characterized by absolute destruction of isolation, under the influence of a robust public information field and increasing trends of virtualization of social reality. Thus, according to scientist E. Savrutska, the openness of the communication space of modern civilization makes a person as if involved in events, the real subject of which is not connected with the one. That is why in the real space of a person's own life, there is a combination, and often the replacement of value systems, spiritual and moral guidelines of the culture ${ }^{16}$. Modern trends that dominate in society convince the scientific world that "human becomes a problem for him/herself." The tension of the world, which is

\footnotetext{
16 Савруцкая Е.П. Коммуникационный аспект инновационных трансформаций в конструировании социальной реальности // Культурологический журнал : Электронное периодическое рецензируемое науч. изд. 2012. № 3 (9).
} 
directly associated with one of the main themes for modern science, namely the transformation processes in culture, is due to the problem of preserving the cultural integrity of human, connection with the world, the own essence.

Under the influence of cultural transformations, there is a change in relations between people, and new images of the real world are formed, which significantly affect the system of cultural values. In the communication processes of a real person as an object of interest and attention on the part of the "other" is replaced by consumer goods, and the Internet as a kind of computer interlocutor gradually takes a dominant place in terms of the person's world.

Modern information and computer technologies allow a person to penetrate the most secret corners of the intimate life of a personality, thereby destroying one's world by changing the worldview. There is a particular communicative situation in which the processes occurring in the communicative space are provided with a large number of entirely new means of accumulation, storage, and transmission of information.

On the one hand, there is a devaluation of cultural, spiritual, moral attitudes, rules, principles, norms, behaviors, on the other - universal values are formed, which, even being blocked in a stable environment, find auxiliary, indirect forms for their development. Their further implementation at a higher taxonomic level becomes a global problem. Thus, globalization contributes to the crystallization of universal value categories that form the architectonics of the new world order. The problem of a psychological dependence on global changes is actualized.

Figuring out the essence of the phenomenon of psychological compensation, scientists, and first of all, representatives of psychoanalysis, emphasize a deep connection over-consciousness, consciousness, and mentality.

By having defined mentality as a particular way of thinking, a warehouse of the human soul, it is necessary to emphasize that mentality is characterized by certain specifics in perceived and interpretation of the world by the individual.

In terms of the analyzing the content of the mentality, the scientists emphasize that the one is represented as a well-established historical experience, forms, and ways of expressing the intellectual and emotional 
reactions, stereotypes of behavior, archetypes of culture and sociopsychological the willingness of social actors" ${ }^{\text {"17 }}$.

Quite an extensive use of the term mentality in everyday life and the presence of its various interpretations in the scientific community indicates a growing interest of researchers to the mentioned phenomenon (L. Batkin, M. Bakhtin, L. Vygotsky, A. Gurevich, G. Duby, S. Krymsky, A. Kulchitsky, S. Rubinstein, A. Strážné, A. Furman, V. Shkuratov, N. Shlemkevych, etc.). It should be noted that in the national tradition of the study of national mentality, although without the use of the concept, associated with the works of N. Kostomarov "Books of the Genesis of the Ukrainian People" and" Two Russian nationalities"18. Later, on the particular problem O. Kulchytsky, Y. Onatsky, B. Cymbalisty, D. Chizhevsky, M. Shlemkevych worked. The researches of the mentioned scientist were represented to the public in 1992 when a collection "Ukrainian soul" was published where the original research concerning the outlook of our people was presented ${ }^{19}$.

A set of different symbols and images reflect the idea of a specific society about the world and, in turn, determine the motives of behavior and actions of people, which are fixed in the minds of people in the process of communication and determine their mentality. It is formed under the influence of natural conditions and social realities, reflects and reveals the picture of the world, which consolidates the unity of the cultural tradition of a particular cultural community. This kind of perception of the world is born in the depths of over-consciousness that claims Freud in the studies of the human soul and the structure of the psyche.

The doctrine of the personal unconscious, substantially supplemented the Swiss psychologist, cultural commentator, and the founder of analytical psychology K. Jung, focusing on the archetypes and the collective overconsciousness, attempting to penetrate the unconscious is more profound than his teacher. Archetype as a collective unconscious is a kind of outcome of the life of the genus (people, ethnos, nation), which is inherited from ancestors and appears as the basis on which the individual psyche grows. Archetypal images, according to Jung, always accompany a person.

\footnotetext{
${ }^{17}$ Кримський С., Заболоцький В. Ментальність // Філософський енциклопедичний словник / ред. кол. : B.І. Шинкарук Є.К. Бистрицький, М.О. Булатов та ін.; Інститут філософії ім. Г.С. Сковороди НАНУ. К. : Абрис, 2002. С. 369-370.

${ }^{18}$ Костомаров М. Книги буття українського народу // Українознавство : хрестоматія. К. : Либідь, 1993. C. 238.

${ }^{19}$ Українська душа / заг. ред. В. Храмова. К. : Фенікс, 1992. С. 56.
} 
They are the sources of mythology, religion, art, culture and through them influence the organization of the life of the people. Thus, Jung adds another dimension to the understanding of the unconscious and thus begins a new perspective of understanding the phenomenon of mentality ${ }^{20}$.

Mentality and culture are close structurally, interrelated, but qualitatively different phenomena, and therefore the categories which they mean contrast. The more fundamental nature of culture as compared to mentality is that different cultures are not able to form a single mentality, although they interact, often contradictory. Based on mentality, a particular type of cultural practices is formed, and this process is quite long, responsible, and ambiguous. However, in both cases, national culture is formed, the features of which various cultural practices are reflected. Thus, by defining mentality as an essential component of socio-psychological self-organization of representatives of a particular cultural practice, scientists note that it is characterized by the unity of attitudes, experiences, thoughts, feelings, and manifests itself in the identity of worldview ${ }^{21}$.

In the three-component structure of mentality, emotional coloring is essential, it appears in the form of a complex range of feelings, moods, temperament features, emotional and volitional aspirations and forms of expression determined by them in images, sounds, colors, the totality of which is not only in everyday life but also in traditions and cultural practices. That is the reason why, determining the cultural and historical conditionality of mentality, scientists note the variability of public attitudes, fluctuations in public opinion, and emotional impulses. "Mobility" of cultural and historical factors, as noted by A. Hutka, can cause significant modifications, deformation of mental attitudes of a particular ethnic group ${ }^{22}$.

The multifaceted phenomenon of cultural practices is characterized by a common opinion about their primary purpose, which is to form a common understanding of the essence of human life. Cultural practices create a single cultural space, a meaningful field of human existence, its cultural socialization. The interaction of cultural practices and a person

\footnotetext{
${ }^{20}$ Кримський С., Заболоцький В. Ментальність // Філософський енциклопедичний словник / ред. кол. : В. І. Шинкарук, С.К. Бистрицький, М.О. Булатов та ін.; Інститут філософії ім. Г.С. Сковороди НАНУ. К. : Абрис, 2002. С. 550.

21 Фурман А.В. Психокультура української ментальності: наук.вид. Тернопіль : Економічна думка, 2002. C. 48.

${ }^{22}$ Хутка О.С. Поняття «національна ментальність» та їі роль в ціннісній системі суспільства // Науковий вісник Академії муніципального управління : зб. наук. пр. Сер. Управління. 2009. Вип. 4 (10).
} 
forms the basis of co-existence, self-determination by the person of their life orientations that is based on the direct interiorization of cultural values, acquiring the character of measuring individual and social life. The process of interaction between cultural practices and human in the modern world, with its various threats and challenges, actualizes the problems of freedom.

The problem of freedom is a rather complex categorical concept. Personal freedom is the absence of various forms of exploitation and oppression, discrimination and persecution, the possibility of committing acts by the will of the person within limits provided for by democratic legislation. It is worth noting that the concept of freedom in our time is often identified with the freedom of choice. The choice seems to be the highest criterion of freedom: there is a choice - there are freedom and development; there is no choice - there is neither one nor the other. Of course, the idea of choice is not the last attribute of freedom.

It is necessary to note that in the second half of the nineteenth century and early twentieth century, people appreciated the freedom through the prism of the negation, rebellion, nihilism. In the early twenty-first century, freedom is understood as a creative, cultural value, dialogue.

Taking into account the deep determination of human behavior by social and historical being, "freedom of choice" becomes a "recognized necessity" for a person (O. Ukhtomsky). No problem goes so far into metaphysical heights and has, at the same time, the most significant practical significance as the problem of freedom.

Human freedom is the will, rationalized, ethical and gnoseological, or involved in the structure of practical and theoretical understanding and have their intentional center. In determining the importance of culture, it is essential to emphasize its levers, namely, a positive impact on human development, the formation of the personality. Defining culture as a particular system of semantic complexes necessary for the person-values which are capable of acting as regulative principles of group behavior, we will designate its value for the development of the individual. Culture enriches its spiritual world, lays the foundations for the formation of a sense of freedom by having an unconditional influence on the content of human life. Culture in all its diversity as one of the spheres of human existence has its inherent levers for human development. Individual human freedom is an integral part of civil freedom, which acquires a new meaning and form in current socio-economic conditions. 
In this context, the question of the role and importance of freedom of choice of cultural practices for the own psychological satisfaction is actualized.

One of the modern cultural trends is the formation of the cultural landscape. O. Lavrenova, who theorizes on the problems of interaction between culture and space, understanding not only the reflection of culture and the creation of images as a result but preferably on the features of the psychological perception of the components of the cultural landscape ${ }^{23}$.

In this context, modern scientific research defines the cultural landscape not only as a geographical environment, nature, or historical memory, but also reflects its practical life of the modern human. Taking the mentioned issue into account, O. Nikitina's research presents the cultural landscape as an existential state of a person, deserves attention ${ }^{24}$.

We pay no less attention to the role of cultural institutions as the main subjects of creation and implementation of cultural practices. Cultural institutions possess all potential opportunities for psychological compensation.

The compensatory function of cultural institutions provides for the creation of necessary conditions for the rest of people from life problems and getting them psychological and emotional discharge.

It is psychologically reasonable to assume that the cultural practices of the modern library contribute to the creation of "zones of personal stability", where the visitor feels more relaxed, confident, and protected than elsewhere. Librarians are consciously working to improve the library environment, from service to design to the surrounding landscape.

A person can receive psychological compensation both from the performance of religious rites as well as cultural, creative practices (reading books, visiting theaters, museums, clubs, concert halls, etc.), tourism or communication with nature, collecting, etc.

Parks are an integral part of the system of psychological compensation of a person. They are organically connected with the general processes of the social and cultural life of modern society. The increasing role, importance, popularity of parks in modern life is connected to the

\footnotetext{
23 Лавренова О.А. Семантика культурного ландшафта : автореф. дис. ... д-ра филос. наук : $24.00 .01 /$ ГОУ ВПО Российский государственный гуманитарный университет. URL: http://dissertation1.narod.ru

24 Никитина А.В. Специфика философско-культурологической репрезентации культурного ландшафта: автореф. дис. ... канд. филос. наук : 24.00.01 / Казанский государственный университет культуры и искусств. Казань, 2013. С. 5.
} 
processes of urbanization of life, the intellectualization of labor, increasing psychological stress on the production, etc. Parks of culture and recreation are characterized by their multifunctionality and diversity of the offered and, accordingly, consumed cultural services, which are designed to meet the demand of all socio-age groups of the population in various types of cultural leisure ${ }^{25}$.

It should be noted that cultural institutions as centers of psychological compensation are not the object of scientific research among scientists of psychological knowledge. However, the role and importance of cultural institutions in the psychological and compensatory recovery of the human are undeniable. The problem of recreation has not yet become one of the priorities in the functioning of Ukrainian cities, although sociologists and psychologists note that, together with the spheres of work and life of the population, recreation has a significant impact on the formation of a unique cultural environment and on improving the quality of human life.

The question of changing educational priorities in training specialists who are able to take into account the trends mentioned above is updated. Professional competence of the modern manager of culture should take into account several related to the own professional activities of knowledge and skills, among which a special place belongs to the knowledge and practice of psychology. Modern training of highly qualified specialists should be based on such an educational program that would take into account the subject area as much as possible. Moreover, it is not only innovation as a static result of cultural practice but also a process of transformation of innovations into socio-cultural, psychological norms, and behavioral models.

\section{CONCLUSIONS}

Having studied and comprehended the thematization of cultural practices in the context of psychological compensation, we have come to the following conclusions:

- Cultural practices are a powerful compensatory tool. The substantial essence of cultural practices allows providing various needs of the person, including psychological ones. The changes taking place in modern Ukraine require us to focus on the features of modern cultural practices, which

\footnotetext{
${ }^{25}$ Копієвська О.Р. Паркова індустрія : підручник. К. : НАКККіМ, 2015. С. 5-6.
} 
unfortunately are not always characterized by positive results and impacts on the consciousness of Ukrainians, especially young people.

- Thematization of the psychologically compensatory phenomenon of cultural practices, their transformations corresponds to the actual problems of the modern development of science and is based on the importance of empirical and theoretical understanding of the scientific, practical potential for the sphere of culture to determine the pressing problems of our time and ways to solve them;

- Issues of the role and importance of cultural practices, their psychological and compensatory potential (resource) for both the individual and society as a whole become particularly relevant. The exclusive role of the research object is outlined in the processes of preservation and formation of mental characteristics of Ukrainians, ensuring freedom of choice, value orientations, and tolerant attitude to each other. Determined by the particular importance of psychological compensation, its functional content in the system of formation of the cultural landscape and the activities of the core network of cultural institutions, in the formation of professional competences of the modern cultural manager, whose educational outcomes should be knowledge and skills in practical psychology.

- There is an urgent need to understand the methodological developments, recommendations for the introduction of psychological compensation in cultural practices, which will solve a significant number of various problems faced by different social and age categories of the population.

\section{SUMMARY}

The role of cultural practices in the context of psychological compensation of the person is investigated and theoretically comprehended in the section. Theoretical bases of cultural practices understanding are analyzed, their contents and essence in the system of providing psychological features as the person, as well as society as a whole, are determined. Meaningfully exclusive psychological and compensatory value of transformation of cultural practices for preservation and formation of mental features of Ukrainians, ensuring freedom of choice, value orientations, and tolerant attitude to each other. The importance of psychological compensation, functional content in the system of cultural 
landscape formation, and activity of the primary network of cultural institutions is actualized. The priority of transformation of professional competence psychological direction for a contemporary cultural manager is underlined.

\section{REFERENCES}

1. Bessonova, O.E. (2006). Handout economy of Russia: Evolution through transformation. Moscow : Rossiyskaya politicheskaya entsiklopediya (ROSSPEN) [in Russian].

2. Vakhstain, V.S. (2008). Practice vs. "Frame": alternative research projects of the everyday world. Sotsiologicheskoe obozrenie, 7, 1, 65-95 [in Russian].

3. Vakhstain, V. (2011). Sociology of everyday life and the theory of frames. St. Petersburg : Yevropeyskiy universitet v Sankt-Peterburge [in Russian].

4. Volkov, V.V., Kharkhordin, O. V. (2008). Practice theory. St. Petersburg : Evropeyskiy universitet v Sankt-Peterburge [in Russian].

5. Dyakov, A.A. (2009). Philosophy and practice: was there a past, is there a present, will there be a future? Nauka. Filosofiya. Obshchestvo : materialy $\mathrm{V}$ Rossiyskogo filosofskogo kongressa. Novosibirsk, I [in Russian].

6. Dyakov, A. (2011). Theory of practice: Socio-philosophical potential of the concept. Izvestiya Saratovskogo universiteta. Filosofiya, Psikhologiya.1, 9-12 [in Russian].

7. Kondratyev, M.Yu., Ilyi, V.A. (2007). Alphabet of a social psychologist-practitioner. Moscow : PER SE [in Russian].

8. Kopiyevska, O.R. (2015). The park industry: a textbook. Kyiv : NAKKKiM [in Ukrainian].

9. Kopiyevska, O.R. (2018). Transformational Processes in the Cultural Practices of Ukraine: Global, Glocal Context and the Local Particularities (the end of XX - the beginning of XXI centuries). Doctor's thesis. Kyiv: NAKKKiM [in Ukrainian].

10. Kostomarov, M. (1993). Books of being of the Ukrainian people. Ukrayinoznavstvo : khrestomatiya. Kyiv : Lybid [in Ukrainian].

11. Krymskiy, S., Zabolotskiy, V. (2002). Mentality. Filosofskiy entsyklopedychniy slovnyk. Kyiv : Abrys [in Ukrainian]. 
12. Lavrenova, O.A. (2010). Semantics of the cultural landscape : Extended abstract of doctor's thesis. Retrieved from : http: // dissertation 1. narod.ru. [in Russian].

13. Mezhuev, V.M. (2009). The values of modernity in the context of modernization and globalization. Informatsionniy gumanitarniy portal Znanie. Ponimanie. Umenie : Filosofiya. Politologiya. Retrieved from : http://www.zpu-journal.ru/e-zpu/2009/1/Mezhuev/ [in Russian].

14. Nastoyashcha, K.V. (2018). Attributions of the concept of practice: conflicts of definition and the search for verifications. Grani: naukovo-teoretychniy almanakh, 21, 1, 56-62 [in Ukrainian].

15. Nikitina, A.V. (2013). Specificity of the philosophical and cultural representation of the cultural landscape. Extended abstract of candidate's thesis. Kazan [in Russian].

16. Nuryshev, G.N. Geoculture: theoretical and methodological foundations. Retrieved from : http: //www.ibl.ru/konf [in Russian].

17. Pochebut L.G. (2005). Mutual understanding of cultures: methodology and methods of ethnic and cross-cultural psychology. Psychology of Interethnic Tolerance. St. Petersburg : Publishing House of St. Petersburg. University [in Russian].

18. Razdina, E.V. (2010). Century Transformation of the national state in the world system of institutions of power under the influence of globalization. Humanitarnyy chasopys : zb. nauk. pr. Kharkiv: KhAI, 2, 121-127 [in Russian].

19. Richard, J. (2012). So what is cultural research? Logos, 1, 80-135 [in Russian].

20. Savrutskaya, E.P. (2012). Communication aspect of innovative transformations in the construction of social reality. Kulturologicheskiy zhurnal : Elektronnoye periodicheskoye retsenziruyemoye nauch. izd. 3(9). Retrieved from: http://www.cr-journal.ru/rus [in Russian].

21. Smirnov, A.V. (2012). Discursive practices as a tool for the study of everyday life. Vestnik Orlovskogo gosudarstvennogo universiteta. Ser. Novye gumanitarnye issledovaniya,.2 (22), 264-267 [in Russian].

22. Ukrainian soul (1992). Ed. Khramov, V. Kyiv : Feniks [in Ukrainian].

23. Furman, A.V. (2002). Psychoculture of Ukrainian mentality: scientific publication. Ternopil : Ekonomichna dumka [in Ukrainian]. 
24. Khutka, O.E. (2009). The concept of "national mentality" and its role in the value system of society. Naukovyy visnyk Akademiyi munitsypalnoho upravlinnya : zb. nauk. pr. Ser. Upravlinnya, 4(10). Retrieved from : http://www.nbuv.gov.ua [in Ukrainian].

25. Epstein, M.N. (2005). Postmodern in Russian literature: textbook for universities. Moscow : Vysshaya shkola [in Russian].

\section{Information about the author:}

Kopiyevska O. R.

Doctor of Cultural Studies, Professor, Head of the Department of Art Management and Event Technologies of the National Academy of Culture and Arts Management 9, Lavrska str., Kyiv, Ukraine 